\title{
The Journey towards the Love for Reading: From the Lens of English Enthusiasts
}

\author{
Nicomedes S. Lumontad' 8 (D) $\triangle$, Amelia Bonotan' 8 (iD) and Rex T. Argate 3 (D) \\ ${ }^{1}$ Faculty, College of Liberal Arts, University of Cebu - Main, Cebu City, Philippines \\ ${ }^{2}$ Faculty, Graduate School, Cebu Normal University, Cebu City, Philippines \\ ${ }^{3}$ Chairperson, College of Teacher Education \& Graduate School, University of Cebu - Main, Cebu City, Philippines \\ $\triangle$ Corresponding Author: Rex T. Argate, E-mail: rargate@uc.edu.ph
}

ARTICLE INFORMATION ABSTRACT

Received: March 08, 2021

Accepted: April 17, 2021

Volume: 3

Issue: 4

DOI: 10.32996/jweep.2021.3.4.4

\section{KEYWORDS}

Reading, English enthusiasts, attitude, Interpretative Phenomenological Analysis
This study described the lived experiences of the English enthusiasts at the University of Cebu - Main Campus. The study used Interpretative Phenomenological Analysis (IPA) through 15 BSED English Majors interviews. The analysis of data generated six themes "Actually, I am not really fond of reading books, but I've learned to enjoy reading love storybooks. They are very entertaining." (Gaining Interest and Love for Reading), "The challenges that I encountered in my journey towards acquiring the love of reading are the unfamiliar words. Whenever I encountered those words, I usually pause and find their meanings." (Dealing with Unfamiliar Words) "I addressed the challenges in positive ways. These only urge me to love reading more." (Context and Comprehension Challenges) "I simply love reading because I can use my imagination. When I read, I feel like I'm the main character of the story." (Attitude towards Reading) "In reading, you will experience things you haven't experienced yet. You choose an author and a genre first before you read. In that way your interest and love of reading will be sustained but exploring is more fun." (Personal Book Choice) "In reading, actually you discover yourself more, especially if you read different genres of books. My journey towards reading is self-discovery." (Realizations through Reading). The study attempts to explain the different factors involved in the love of reading. These are gaining interest and love of reading, dealing with unfamiliar words, context and comprehension challenges, attitude towards reading, personal book choice, and realizations through reading. The English enthusiasts encountered some difficulties in reading various texts, passages, and other English classics. However, their enduring interest, love, and passion for reading transcend all forms of reading complexities. In contrast, some students may lack interest and motivation in reading. They tend to be superficial readers, or they just read when they are told to do so. Reading for them is dull and boring. Thus, the English enthusiasts may share their lived reading experiences with those reluctant and passive readers, and they may become more interested and motivated to read beyond the parameters of academic requirements.

\section{Introduction}

One of the most important skills that higher education students should possess is reading. All academic endeavours at the college level have to deal with reading. College students should be able to read understand what they are reading. A college student who wants to become a good reader, writer, and good speller should spend more time reading (Krashen, S. 1993). Reading as a macro skill in communication can be an indisputable underpinning for more learning in all disciplines. It is a concrete anchor of language education, and it remains a true backbone of most learning. Students are exposed to more challenging reading passages or texts as students go up - former Department of Education Secretary Bro. Armin A. Luistro emphasized the importance of assessing students' reading capabilities as reading is still the foundation of all academic learning. He added that if a pupil fails to master

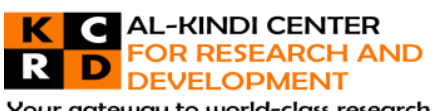

Your gateway to world-class research

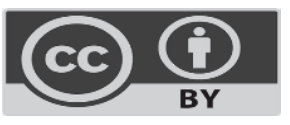

Published by Al-Kindi Center for Research and Development. Copyright (c) the author(s). This open access article is distributed under a Creative Commons Attribution (CC-BY) 4.0 license 
basic reading skills at the outset, it will be a constant struggle for him or her to succeed in other disciplines, thus minimizing their opportunity to develop into a productive, literate individual.

Aside from reading skills, the students should also have the interest to read to benefit from reading and be a reader. This implies that students should have enough determination or, simply put, inner impetus to read for information, purpose, and pleasure. Thus, reading activity will be more meaningful and beneficial if the reading interest which precedes the reading rooted in one's intrinsic motivation, not in the force of other parties or extrinsic rewards (Cambria \& Guthrie, 2010). One may only engage in love for reading if he or she takes reading beyond the usual reading comprehension tests and scores. Studies show that one can write better if he or she reads more. The striking evidence on the impact of reading for pleasure or, simply, self-selected recreational reading is overwhelming. It is the major source of our reading abilities, acceptable writing styles, vocabulary and spelling skills, and understandable grammatical constructions.

Reading ability is an essential factor or tool in overall academic success, and people of all ages who lack basic reading skills, a main part of literacy, often find themselves on the edges of societal standing (Brozo, W. G., 2002). Verbal intelligence will be enhanced to those who read a lot, thus making them smarter individuals (Cunningham, A. \& Stanovich, K. 2001). Jacobs considers reading one of the "great human delights" (Jacobs, Alan 2011). Tons of evidence suggest that recreational reading is one of the best ways to develop a student's reading, writing, vocabulary, and spelling ability. This is true to learners who study English as a first language and English as a second and foreign language (Krashen, S. 2011). English majors or not, they are expected to learn more about the intricate components of grammar and literature as they continue to immerse themselves to the world of reading.

Like the other macro skills, love for reading is a gradual process. Students, particularly college students may become independent readers if they have absorbed the value, impact, and love for reading. Further, independent reading is affirmed beneficial for students' enrichment of vocabulary, improvement of reading comprehension, verbal fluency, academic success, as well as understanding and appreciation of students' own life, environment and society (Krashen, 1993; Whitten, Labby \& Sullivan, 2016; Renandya, 2007). This only proves that independent reading is closely correlated with the love for reading, making broadminded, flexible, and successful individuals. Reading interest is defined as the extent to which an individual feels excited to engage in reading written materials and delighted to find new information (Cambria \& Guthrie, 2010; Thomas, 2001). This is one of the compelling factors to augment one's love for reading.

Reading a popular book with full interest and enthusiasm is a more valuable experience than pretending or complying. According to Anne Reeves, teenage readers want to read about various characters similar to themselves and with whom they can identify with. With this, readers may empathize with the characters of the short story or novel. Teenage readers are not that eager to read stories about young people who lose control over their own lives or fail in any way. They do look for literature that confirms the notion that they can be successful in adulthood (Reeves, A. 2004). In her book "The Reader, the Text and the Poem," Rosenblatt explains that aesthetic reading is when readers read creatively and brings individual background knowledge, beliefs, and context into the reading (Rosenblatt, L. 1994).

This phenomenological research described the lived experiences of the English enthusiasts/majors of the College of Teacher Education (CTE) at the University of Cebu - Main Campus. It offers interesting insights from the English enthusiasts/majors themselves as they did share the positive impact and influence on the love for reading. The outcome of the said research may encourage school administrators to appropriate more reading spaces or centres aside from the university library.

\section{Philosophical Stance}

No researcher enters the field with a totally blank sheet but would have his or her own disciplinary training that provides perspectives from which to investigate the problem. These different bodies of knowledge supply theoretical sensitivity that support understanding of data that were being collected during the research process. Thus, a philosophical basis is required to conduct the study to provide grounding on the perceptual perspective on what to look for and how to methodologically describe the phenomenon. Thus, it discusses the ontological, epistemological, axiological, methodological and rhetorical assumptions of qualitative research as an important framework of the study.

\section{Ontological Assumption}

Ontology is a concerned with what kind of world we are investigating, the nature of existence, and the structure of reality. Guba (1989) states that the ontological assumptions are those that respond to the question 'what is there that can be known?' or 'what is the nature of reality?'

With these given definitions of ontology, let us now identify the ontology used in the study. The study uses an ontology which is essential of a social world of meanings. In this world, the researcher assumes that the world he investigates is a world populated 
by human beings who have their own thoughts, interpretations and meanings. The researcher investigates this reality using an interpretive design such as interviews in order to interpret the informants' inner thoughts and feelings.

The researcher believes that realities are constructed by the social actors which realities are relative that no reality is considered truer than any other; these realities are within the context of the social actors' lives. The study also adopts a realistic ontology that follows the physical world in which an assumption on the existence of a world of causes and effect. On this study, an assumption is made that there are some realities that exist in the world and may affect the students' love for reading.

\section{Epistemological Assumption}

The concern of epistemology is to explain and understand how we would know what we know (Crotty, 2003). Epistemology is concerned with providing a philosophical grounding that can help decide what kinds of knowledge are possible and how we can ensure this this knowledge are both adequate and legitimate (Maynard, 1994).

The study is using constructionism as its first epistemological stance. In the constructivists' perspective, knowledge is constructed as the product of the interaction between man and his world and is developed and transmitted within the social context (Crotty, 2003). Rather than being discovered, meaning is being constructed.

Objectivism is also utilized in this study as the epistemological stance. According to objectivist epistemology, meaningful reality exists as such independent from the operation of any consciousness (Crotty, 2003). It means that the mind of the investigator is thought to be separate from the world of objects, on what is investigated, as used in this study.

\section{Axiological Assumptions}

The axiological assumption has to do with values. Positivists believe that the process of research is free of values because they consider themselves as independent of the study. They are interested in the interrelationship between the objects they are studying, and they believe that their research does not affect these objects in any way. On the other hand, interpretivists subscribe to the idea that the researcher has values that help him figure out what is considered to be facts and help him interpret them (Hussey, 2009).

The researcher believes that values are inevitable and desirable. Often, research has a value-laden purpose. The researcher is not hesitant to be openly fervent about pursuing the project. Due to the inevitability of biases, he has to include personal interpretations together with the informants' interpretation.

\section{Methodological Assumption}

Methodology refers to a plan of action, system, procedure or strategy that lies behind the choice and use of specific methods and links the choice and use of methods to the expected output (Crotty, 2003). Its aim is to evaluate, justify and describe the use of particular methods (Wellington, 2000).

In positivist-oriented research, the concepts should be explained in a way that they can be measured. It uses samples, focuses on objective facts and phrases hypotheses. The interpretivist-oriented research is done by examining a small sample during a certain period of time. The analysis conducted should be able to understand what is happening in a situation and find patterns that are present in other situations (Hussey, 2009).

\section{Rhetorical Assumption}

According to Hussey (2009), the rhetorical assumption has to do with research language. The style is normally formal for positivists and is illustrated in passive voice. This is done in order to create an impression that research is more objective from what is publicly known. The language of research for interpretivists is less explicit; normally, it is appropriate to write in the first person, reflecting that the researcher is involved in what is being researched. However, it depends on the persons who are writing the research paper to ensure the objectivity of the results of the study.

The researcher uses a language that is both engaging and personal. This includes the use of the definition of terms which is defined operationally. Some terms in the text have multiple definitions, including multiple definitions provided by the participants.

The adopted ontology and epistemology in this research accept that knowledge is not static, but it is always emerging and transforming, and both researcher and the informants interpret it. Meaning is conveyed through dialogue and action. Within a dialogue and action are the embedded understanding, experience, and emotion. Only through interaction and discourse can 
meaning be unlocked and conveyed to the informants. From this perspective, the descriptive narrative provides a method that enables the researcher to adduce true meaning and understanding of data.

\section{Objectives of the Study}

This paper delved into describing the English enthusiasts' or majors' journeys on the love for reading. It also focused on each participant's lived experience of the phenomenon.

Interview Questions

1. As an English enthusiast, kindly share your experiences in your journey towards the love for reading?

2. What were some challenges that you encountered in your journey towards acquiring the love for reading?

3. How did you face and address those challenges?

4. How did you sustain your interest and love for reading?

5. What can you recommend to those students who do not yet love to read?

6. What is the meaning of your journey towards the love for reading?

\section{Materials and Method}

The study used Interpretative Phenomenological Analysis to identify the lived experiences of the English enthusiasts at the University of Cebu - Main Campus, College of Teacher Education, Cebu City. After conducting the interview, Collaizzi's Method of Data Analysis was used. It included transcriptions, analyses of significant statements, formulated meanings, and themes. Data are collected through a structured interview using a voice recorder and written descriptions on the informants' demographic profiles. Prior to the data collection, the researcher piloted first the interview to another set of informants. This allowed the researcher to establish if the interview questions were understandable and capable of answering the research problems. Using purposive sampling, a total of 15 informants participated in the study.

Table 1. Profile of the Student-Participants

\begin{tabular}{|c|c|c|c|c|c|}
\hline Participants & Age Range & Civil Statu & School & Course & Specialization \\
\hline 1 & 18 & Single & University of Cebu & BSED & English \\
\hline 2 & 18 & Single & University of Cebu & BSED & English \\
\hline 3 & 18 & Single & University of Cebu & BSED & English \\
\hline 4 & 18 & Single & University of Cebu & BSED & English \\
\hline 5 & 18 & Single & University of Cebu & BSED & English \\
\hline 6 & 18 & Single & University of Cebu & BSED & English \\
\hline 7 & 18 & Single & University of Cebu & BSED & English \\
\hline 8 & 18 & Single & University of Cebu & BSED & English \\
\hline 9 & 18 & Single & University of Cebu & BSED & English \\
\hline 10 & 18 & Single & University of Cebu & BSED & English \\
\hline 11 & 18 & Single & University of Cebu & BSED & English \\
\hline 12 & 18 & Single & University of Cebu & BSED & English \\
\hline 13 & 18 & Single & University of Cebu & BSED & English \\
\hline 14 & 18 & Single & University of Cebu & BSED & English \\
\hline 15 & 18 & Single & University of Cebu & BSED & English \\
\hline
\end{tabular}

Table 2. Codes and Themes

Codes

Themes

- reading books by chance and find them enjoyable

Gaining Interest and Love for Reading

- realizing the necessity of reading as an English major Gaining Interest and Love for Reading

- $\quad$ asking others on what books to read Gaining Interest and Love for Reading

- complex word meanings Dealing with Unfamiliar Words

- denotative vs. connotative words Dealing with Unfamiliar Words

- taking note on some vocabularies Dealing with Unfamiliar Words

- reading twice or thrice to comprehend Context and Comprehension Challenges

- reading more to comprehend Context and Comprehension Challenges

- $\quad$ take a rest and wait for few minutes before rereading it

- appropriating time to read Context and Comprehension Challenges

- borrowing books in the library Attitude towards Reading Attitude towards Reading 


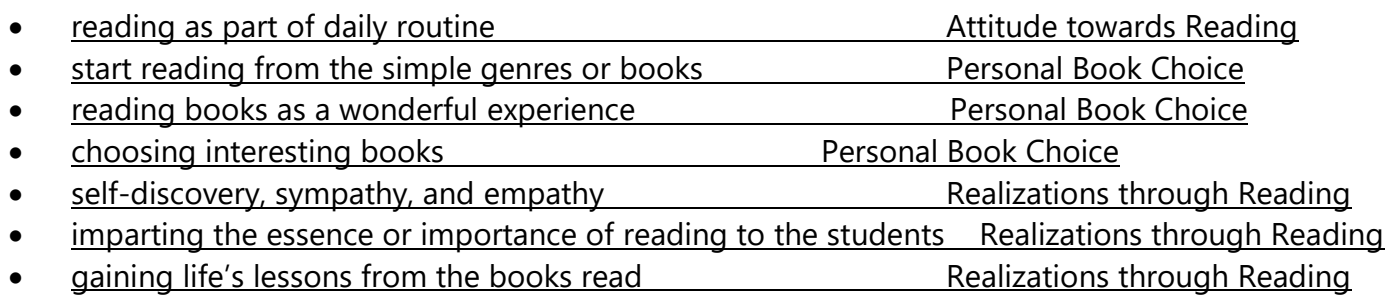

\section{Themes}

A. "Actually, I am not really fond of reading books, but I've learned to enjoy reading love story books. They are very entertaining. Those can bring you to other dimensions." (Gaining Interest and Love of Reading) describes one's initial perceptions on reading. Once a reader enjoys what he or she is reading, then he or she becomes more interested to read. Others may find reading interesting if the books they are reading give them space for wider imagination and information.

B. "The challenges that I encountered in my journey towards acquiring the love for reading are the unfamiliar words. Whenever I encountered those words, I usually pause and find their meanings." (Dealing with Unfamiliar Words) implies enduring efforts on the part of the reader to identify the meanings of unfamiliar words denotatively and connotatively. Others tend to lose focus in reading because of some unfamiliar words, however, knowing the meanings of those unfamiliar words is a vital thing to consider as part of understanding the book or text read.

C. "I addressed the challenges in positive ways for those only urge me to love reading more." (Context and Comprehension Challenges) takes context and comprehension challenges in reading in a positive note. The reader may use his or her higher order thinking and reading skills to further comprehend what he or she is reading.

D. "I simply love reading because I can use my imagination. When I read, I feel like I'm the main character of the story. Reading gives me freedom and a peace of mind." (Attitude towards Reading) elaborates the impact of reading. A reader takes reading in a more personalized angle.

E. In reading, you will experience things you haven't experienced yet. You choose an author and a genre first before you read, in that way your interest and love of reading will be sustained but exploring is more fun." (Personal Book Choice) manifests the reader's strong desire to read by choosing books that are close to his or her mind and heart. This also includes reading not just for serious purposes but for fun or relaxation.

F. "It is self-discovery. In reading, actually you discover yourself more, especially if you read different genres, different genres of books. My journey towards reading is self-discovery." (Realizations through Reading) discusses the purpose, goal, and impact of reading towards the self. This enhances one's self-concept and esteem as he or she discovers more insights or realizations in life by reading varied books and genres. A reader in this stage takes reading in a higher level of literacy and literary perspective and experience.

\section{Results and Discussion}

The results of the study showed that six themes were generated from the interviews. These are the following: "Actually, I am not really fond of reading books, but I've learned to enjoy reading love storybooks. They are very entertaining. Those can bring you to other dimensions." (Gaining Interest and Love for Reading), "The challenges that I encountered in my journey towards acquiring the love of reading are the unfamiliar words. Whenever I encountered those words, I usually pause and find their meanings." (Dealing with Unfamiliar Words) "I addressed the challenges in positive ways for those only urge me to love reading more." (Context and Comprehension Challenges) "I simply love reading because I can use my imagination. When I read, I feel like I'm the main character of the story. Reading gives me freedom and a peace of mind." (Attitude towards Reading) "In reading, you will experience things you haven't experienced yet. You choose an author and a genre first before you read. In that way, your interest and love of reading will be sustained but exploring is more fun."(Personal Book Choice) "It is self-discovery. In reading, actually you discover yourself more, especially if you read different genres, different genres of books. My journey towards reading is selfdiscovery." (Realizations through Reading). These are the different factors involved in the love for reading - gaining interest and love of reading, dealing with unfamiliar words, context and comprehension challenges, attitude towards reading, personal book choice, and realizations through reading.

Theme No. 1"Actually, I am not really fond of reading books, but I've learned to enjoy reading love story books. They are very entertaining. Those can bring you to other dimensions." 
Gaining interest and love for reading is viewed as one of the factors in switching one's negative perceptions of reading like feeling bored or dull while reading to reading with pleasure. One participant said "my journey towards the love of reading actually didn't start until 2012. I develop this habit of reading gradually because it's hard to be interested in something that you're not interested in the first place. So, my reading journey gradually develops." Another participant said "it was somehow a tough journey because at first I didn't really find any interest in reading, but as I took the journey to be an English major, I started to realize that it is very important especially when we talk about the content that I'm going to speak. So, reading and speaking are really connected. Little by little, I started to love reading. I actually asked my classmates and friends who are fond of reading to suggest or recommend some books to me then I started to appreciate reading as a wonderful experience." The participant's interest and love of reading is shown in this statement - "my experience in my journey towards the love of reading is really challenging. Sometimes my parents scold me because I am always holding my phone and reading wattpad." Thus, the three participants have shown their enduring interest and love of reading despite some barriers they have encountered. Reading books by chance and finding them enjoyable, realizing the necessity of reading as English majors, and also asking others on what books to read are the concrete ways of gaining interest and love of reading.

This study is anchored on Reader-Response Theory. The reader's re-creation of the literary piece within his or her own mind is the reader's re-creation. Its main theorists include Stanley Fish, David Bleich, and Wolfgang Iser. Reader-Response theorists actually think that readers are active participants who create a work of literature in the process of reading it. The meaning of a text, according to Reader-Response theorists, exists somewhere between the words on the page and the reader's mind.

Theme No. 2 "The challenges that I encountered in my journey towards acquiring the love for reading are the unfamiliar words. Whenever I encountered those words, I usually pause and find their meanings."

Dealing with unfamiliar words is one of the impediments that a reader has to overcome. Some readers may even lose their interest in reading when they encounter unfamiliar words and don't know their meanings. Others may quickly resort to dictionary meanings of those unfamiliar words without taking into consideration the contextual and inferential meanings of those unfamiliar words. By learning those unfamiliar words denotatively, connotatively, and inferentially, they would enjoy and learn what they are reading. One participant said that "there are also other challenges like other vocabularies I have not encountered yet. I still stutter a little bit in reading, but thanks to perseverance, I manage to gain this level of fluency." A reader has to continue reading as he or she gets the meanings of unfamiliar words in various ways. Another participant said "I use dictionary to find the meanings of the words." However, knowing or identifying the meanings of unfamiliar words goes beyond the denotative surface. The third participant said that "the challenges that I encountered in my journey towards acquiring the love of reading are the unfamiliar words. Whenever I encountered those words, I usually pause and find their meanings." In reading different books or any printed materials, the readers have to be more open-minded and diligent in analyzing the meanings of the unfamiliar words denotatively, contextually, and inferentially.

Theme No. 3 "I addressed the challenges in positive ways for they only urge me to love reading more."

Context and comprehension challenges are truly indispensable as readers would have grasped the total understanding or comprehension of the texts or books read by interpreting them accurately. One may read one, twice, or several times to fathom what he or she is reading. That in itself is already a challenge. One participant said "facing all those obstacles I had a help with my mom, I make her tell me the story at night and she reads it to me in a way I can understand. Also we all needed help from the good old dictionary to understand words which we are uncertain of what it meant. Facing difficulties in reading just needs a small help from reference books and from the grownups to understand difficult books." Thus, these context and comprehension challenges encourage the readers to move more, to really read more. Another participant said that "by reading a lot - magazines, newspapers, or books. Those are great tools to boost your reading skills." To conquer difficulties or challenges in reading, it is important to read varied books. The third participant takes the challenges in reading like the challenges in life - "in the challenges that I have encountered towards my journey in the love of reading, there is always one absolute way that I always think of. It is to remind me that in life, there will always be challenges and problems, and we must learn how to deal with them and find ways to better understand things and overcome these hard times." These context and comprehension challenges in reading have helped deepen one's analyses and interpretations of the texts and books read.

Theme No. 4 "I simply love reading because I can use my imagination. When I read, I feel like I'm the main character of the story. Reading gives me freedom and a peace of mind."

Attitude towards reading is equated to having positive attitude in life as the adage says "one's attitude, not the aptitude will determine one's altitude." In reading, one has to possess the right attitude in reading as he or she is dealing with the experiences of others expressed in various reading platforms. One participant said "I sustain my passion for reading by browsing on the internet for more interesting books I can read. Also I usually go to a bookstore where I can just sit there and read a book all day. This benefits 
me as a student because it helps me be more creative in delivering my thoughts to other people. Reading is also vital for every person in their future careers for they must use their communication skills." Another participant said "I sustain my interest and love of reading by not stopping in reading books. I keep on searching books that will pick my interest. Now, that I'm in college and since my course is related to reading, I indulge myself in books more. I buy books that caught my attention and of course if that book content is worthy." The third participant also said "Whenever I feel the world has turned its back on me, I tend to pull some books or read some fan fiction stories. I always make sure that I have something to read like saving some online books on my cell phone library. It's like letting the feeling flow out of my system." Thus, these readers cultivate the appropriate attitude towards reading as they have devoted time, effort, passion, and enthusiasm in reading.

Theme No. 5 "In reading, you will experience things you haven't experienced yet. You choose an author and a genre first before you read, in that way your interest and love of reading will be sustained but exploring is more fun."

Personal book choice is related to Drop Everything and Read (DEAR) time. It is a time for independent reading by both students and teachers. Every person in the class is to drop everything and read. DEAR time takes in consideration a variety of student interests and ability levels because each student selects for himself or herself the book or books he or she wishes to read. One participant said "students should read more often because through this, they can enhance their vocabulary, their critical and thinking skills. It can help them to learn more words and by it they can apply it on every situation. Moreover, this will help them to be more expressive on what they have to say. Students should love to read because in this way, they will tend to start writing too, and writing is very useful and significant in everyday journey." Another participant said that "the only thing I can recommend for people who are not yet a fan of reading I suggest letting them read stories that fit to their liking. Most books are so typical that people just find them boring to read for they already know how the story will end or that the story is too cliché." The third participant also said "I'll recommend or ask them to read books, novels, newspapers, or magazines which get their interest or likes. I'll tell them how reading helps them to be knowledgeable and also, it makes them as travelers." Personal book choice highlights and signifies the education parlance of individual learning differences and uniqueness.

Theme No. 6 "It is self-discovery. In reading, actually you discover yourself more, especially if you read different genres, different genres of books. My journey towards reading is self-discovery."

Realizations through reading are about self-discovery and essence of life in reading. Thus, through reading, one can be more introspective and imaginative. One participant said "my journey in reading is that I got to be in different places imaginable. The perks of reading are that I can be in someone else's shoes and know what's on their mind. These experiences or so called "journeys" are beyond compare. You can be at new places but nothing compares when you just sit on a chair and go on an adventure of a lifetime without spending your money or tiring your feet." Another participant shared that "as English major, I think the meaning of my journey towards reading is that it is a necessity because I can widen the vocabulary that I have. In the near future, I can share my students the essence or importance of reading." The third participant also said that the meaning of my journey towards the love of reading is like a river. It keeps on flowing or I keep on reading and reading even if there are some hindrances. Reading in itself is a journey, and it gives wide-ranging indelible significant human experiences. The English enthusiasts' journey towards the love of reading may vary, but there is one thing in common - they do love, value, or simply appreciate the purpose of reading.

\section{Conclusion}

The journey towards the love for reading starts with the readers. They may not be fond of reading but have found out its value later, and then they become too interested in reading. The said journey continues if the readers or English enthusiasts would ask their teachers, friends, and other learned individuals about the books they have already read, and the latter may suggest those books to them. Further, the English enthusiasts would always encounter unfamiliar words while reading, and they have to analyze their meanings denotatively, connotatively, and inferentially. The English enthusiasts' context and comprehension skills would take a greater leap if they use higher-order thinking skills and apply close or analytical reading skills. A reader has his or her own purpose of reading. He or she reads for information, pleasure, or imagination. An English enthusiast possesses the right attitude towards reading when he or she has spent time, effort, and passion for reading. Moreover, independent English enthusiasts choose the books they desire most. The books they have chosen, read, and internalized are those books that can sustain their interest and love for reading. Reading is self-discovery. The English enthusiasts who are lovers of books can draw meaningful and relevant experiences from their reading books. They may have influenced some education students to look and embrace reading from a new perspective. This may lead the English enthusiasts to the kind of life they want to live with.

Funding: This research received no external funding from any public or private entity or organization.

Conflict of Interest: The authors declare no conflict of interest in this research. 


\section{References}

[1] Brozo, W.G. (2002). To Be a Boy, to Be a Reader: Engaging Teen and Preteen Boys in Active Literacy. Newark, DE: International Reading Association.

[2] Cambria, J. \& Guthrie, J. T. (2010). Motivating and engaging students in reading. The NERA Journal, 46, (1), 16-29. Retrieved from http://www.literacyconnects.org/img/2013/03/ Motivating-and-engaging-students-in-reading-Cambria-Guthrie.pdf

[3] Crotty, M. (2003). The Foundations of Social Research: Meaning and Perspectives in the Research Process, 3rd edition. London: Sage Publications.

[4] Dawley, D. (2004). Leader Succession: Does Gender Matter? The Leader and Organization Development Journal, 25 (8), 678-690.

[5] Cunningham, A. \& Stanovich, K. (2001). What Reading Does for the Mind? Journal of Direct Instruction, 1(2), 137-149.

[6] Guba, L. (1989). Fourth Generation Evaluation. London: SAGE Publications.

[7] Hussey, R. (2009). Business Research: A Practical Guide for Undergraduate and Posgraduate Studies. New York: Macmillan International Higher Education.

[8] Jacobs, Alan (2011). The Pleasures of Reading in an Age of Distraction. New York. Oxford University Press.

[9] Krashen, S. (1993). The Power of Reading - Insights from the Research. USA: Libraries Unlimited.

[10] Krashen, S. (2011). Free Voluntary Reading. United States: Libraries Unlimited.

[11] Maynard, M. (1994). Methods, Practice and Epistemology, in Mary Maynard and Jane Purvis (Eds.), Researching Women's Lives from a Feminist Perspective . London: Taylor and Francis.

[12] Reeves, A. (2004). Adolescents talk about reading: exploring resistance to and engagement with text. Newark: International Reading Association.

[13] Rosenblatt, L. (1994). The Reader, the Text, and the Poem. The Transactional Theory of the Literary Work. United States: Southern Illinois University Press.

[14] Wellington, J. (2000). Educational Research: Contemporary Issues and Practical Approaches . London: Continuum.

[15] Whitten, C. Labby, S. \& Sullivan, S.L. (2016). The impact of pleasure reading on academic success. The Journal of Multidisciplinary Graduate Research, 2, (4), 48-64. Retrieved from http://www.shsu.edu/academics/education/journal-of-multidisciplinarygraduateresearch/documents/2016/WhittenJournalFinal.pdf 